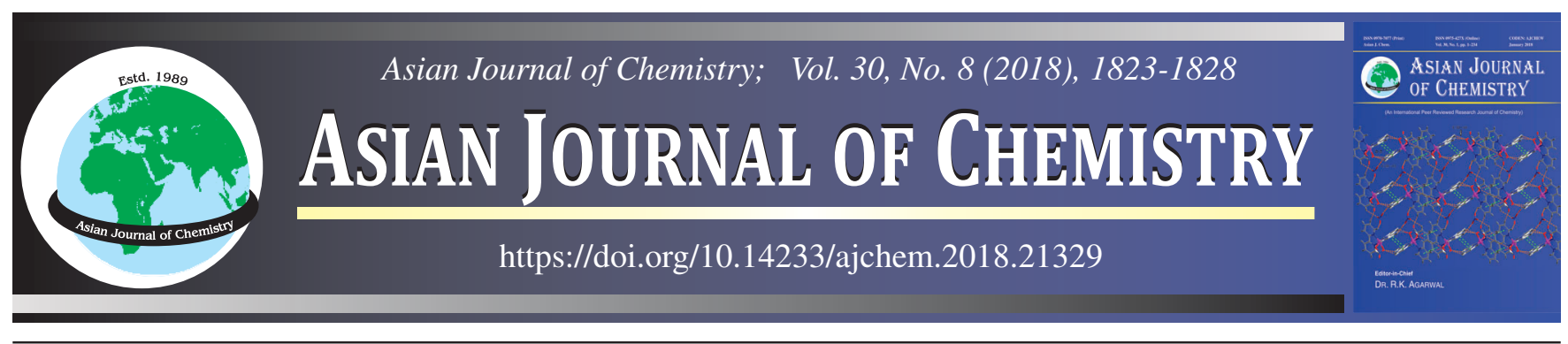

\title{
Preparation and Characterization of Activated Carbon Produced from Eriobotrya japonica Seed by Chemical Activation with $\mathrm{ZnCl}_{2}$
}

\author{
Fevzi KiLiçEL ${ }^{*}$ and Hacer Sibel Karapinar
}

Department of Chemistry, Kamil Özdag Sciences Faculty, Karamanoglu Mehmetbey University, Karaman, Turkey

*Corresponding author: E-mail: fevzi@kmu.edu.tr

Received: 13 March 2018;

Accepted: 10 May 2018;

Published online: 30 June 2018;

AJC-18981

This study reports the utilization of Eriobotrya japonica seed in activated carbon arranging by chemical activation with $\mathrm{ZnCl}_{2}$ agent and the effect of carbonization situations surface properties. The influences of diverse activation temperatures $\left(500,600,700{ }^{\circ} \mathrm{C}\right)$ on the pore structure properties of activated carbons were discussed by using $\mathrm{N}_{2}$ adsorption/desorption isotherms, scanning electron microscopy, thermogravimetric analysis, Fourier transform infrared spectroscopy and X-ray diffraction. The conclusions indicated that the carbonization temperature have favourable effect on Brunauer-Emmett-Teller (BET) surface field, aggregate pore volume. The highest Brunauer-EmmettTeller surface area of activated carbon produced at $700{ }^{\circ} \mathrm{C}$ was $1079 \mathrm{~m}^{2} / \mathrm{g}$, total pore volume was $0.52 \mathrm{~cm}^{3} / \mathrm{g}$, carbonization time was $2 \mathrm{~h}$ and impregnation rate was $1 / 1$. Eriobotrya japonica activated carbon (EJAC)- $\mathrm{ZnCl}_{2}$ can be considered as an ideal low-expense and ecofriendly adsorbent.

Keywords: Eriobotrya japonica seed, Chemical activation, Activated carbon, Characterization.

\section{INTRODUCTION}

Activated carbon has important adsorbent, peripheral, thermal, mechanical and electrical features for new practices of activated carbon [1]. It is a highly ambidextrous substance with wide surface field, wide interior surface field, pore volume, well chemical steadiness, diverse oxygen-having functional groups on the surface. Because of its perfect adsorption ability, it is extensively usaged in refinement and distinction in numerous industrial operation inclusive medical usage, gas storage, contaminant and smell rustication, gas decomposition and catalysis [2,3]. Activated carbons are manufactured from distinct crude materials of organic origin that are rich in elemental carbon, including biomass waste. The selection of the crude material for the manufacturing of activated carbon is decided by the ultimate designation of the activated carbon as well as the availability and cost of the raw material [4]. Activated carbon can be produced such as agricultural wastes, inclusive a corn crust [5,6], peanut crust [7], cotton handle [8], coal, wood, coconut shell, peat [9], almond crust [10], date palm [11], rice shell [11], hazel nut [12], walnut shells [13]. There are two significant process to manufacturing activated carbon [14]: (a) Carbonization which is pyrolysis of the pioneers in an inert atmosphere. Along this process, the organic materials carbon ingredient increases and the constricted or plugged pores are created. Carbonization warmth of cellulosic biomass is at under than $800{ }^{\circ} \mathrm{C}$ and (b) Activation is a method used to further improve pores. There are two types of chemical activation and physical activation. Throughout physical activation, a substance is carbonized in an inert atmosphere and after that activated by vapour or carbonic-acid gas to improve inner porousness. The activation temperature for cellulosic carbon is between 800 and $1000^{\circ} \mathrm{C}[15,16]$. In chemical activation, the raw sample is carbonized by mixing with activation agents like zinc chloride, phosphoric acid, sodium hydroxide and potassium hydroxide $[17,18]$. Chemical activation generally gets location at lesser temperature and smaller process time than physical activation $[15,19]$. The energy spending and the cost are also decreased by inferior temperatures $[15,16]$. In addition to, chemical activation keeps bigger surface field and more elevated carbon efficiency than physical activation [19]. Usually, the activation temperature, activation time, impregnation ratio, carbonization conditions, heating conditions, nitrogen flow rate and activation agents are the most important factors impressing the surface fields and pore volumes of the produced activated carbon [20,21]. In this study, activated carbon is produced from Eriobotrya japonica seed by chemical activation with $\mathrm{ZnCl}_{2}$. The characterization of the produced activated carbons are determined by SEM, BET, FT-IR, TGA and XRD analyzes.

\section{EXPERIMENTAL}

Eriobotrya japonica seed was used activated carbon production in this work and was collected from markets in 
spring and summer in Karaman Turkey. The Eriobotrya japonica seed was separated from the fruit and dried by warming at 80 ${ }^{\circ} \mathrm{C}$ during night. After that, the crude material was milled in grinder and screened to 20-200 mesh grain dimension by standard sieves. The obtained samples were stored in sealed containers until the experimentation.

All reagents (analytical grade $\mathrm{AgNO}_{3}, \mathrm{HCl}, \mathrm{ZnCl}_{2}$ and $\mathrm{H}_{2} \mathrm{O}$ ) were bought from Merck. $\mathrm{pH}$ studies were done usage a $\mathrm{pH}$ meter (Model Cyberscan 510). The FT-IR spectra for functional group determination were recorded in $\mathrm{KBr}$ discs on a spectrophotometer (Model Perkin Elmer-400 Series). A scanning electron microscopy (SEM, HITACHI S-520) was utilizationed for scanning the adsorbent surface. The outer and micropore surface fields, sum pore, micropore capacity and pore size distribution were obtained with the Brunauer-Emmett-Teller (BET) method (Micromeritics ASAP 2020). Powder X-ray diffraction (XRD) models of the examples were registered at room temperature on the Bruker D8 Advance diffractometer handling $\mathrm{CuK}_{\alpha}$ radiation. The thermal evolution of the precursor and $\mathrm{ZnCl}_{2}$ impregnated samples were studied by the thermogravimetric analysis (TGA-50 analyzer) from room temperature until $1000{ }^{\circ} \mathrm{C}$ at a ratio of $10^{\circ} \mathrm{C} \mathrm{min}^{-1}$ with a $\mathrm{N}_{2}$ flow rate of $100 \mathrm{~mL} \mathrm{~min}^{-1}$. The total weight losses of the examples were detected from the corresponding TGA curves.
Preparation of activated carbons: The preparation of the activated carbon (AC) primarily contains carbonization and activation. The aim of carbonization is to get first pore form for activation and suitable carbon concentrate. The aim of activation is to compose new pores and widen the surface field of activated carbon. The flow scheme for the production of activated carbon is given in Fig. 1.

The Eriobotrya japonica powder was impregnated into the zinc chloride with rates $1 / 1(10 \mathrm{~g} / 10 \mathrm{~g}) .150 \mathrm{~mL}$ of distilled water was joined to the mixture. The blend was kept to stand at room temperature for 1 day. The mixtures were dehydrated in an oven at $110^{\circ} \mathrm{C}$ throughout $24 \mathrm{~h}$. Carbonization of the precursor is applied in a hollow cylindrical rust proof steel reactor of $30 \mathrm{~cm}$ in width. The reactor has an inlet and a gas outlet. It is warmed with a tubular oven (Model Protherm) equipped by a heat programmer controller. This system allows the management of the temperature rate, the rise level and the analyses duration of the final temperature. The examples were warmed to last temperatures of $500,600,700{ }^{\circ} \mathrm{C}$ with $5{ }^{\circ} \mathrm{C}$ $\mathrm{min}^{-1}$ warming ratio for residence time of $2 \mathrm{~h}$. Finally, temperature drop until room temperature. The activation is carried out by using nitrogen $\left(9,880 \mathrm{mLmin}^{-1}\right)$ during the hall experiment (Fig. 2). After cooling to room temperature, the produce activated carbon was bathed with $2 \mathrm{M} \mathrm{HCl}$ solution by warming

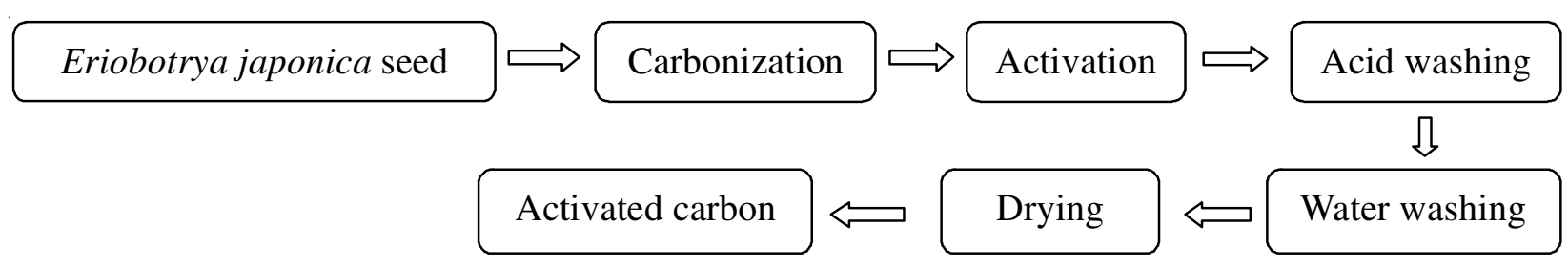

Fig. 1. Flow diagram of preparation of activated carbon

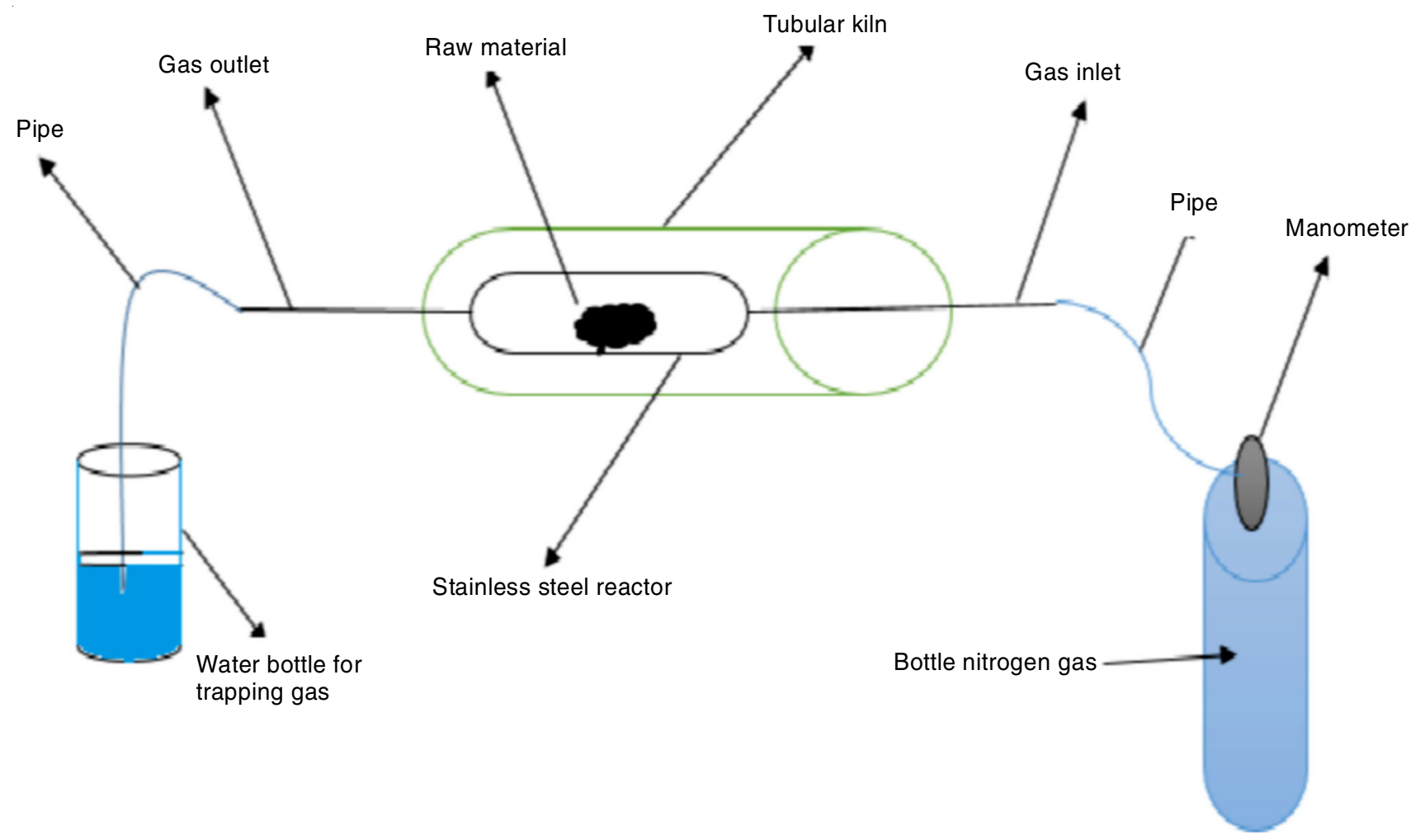

Fig. 2. Furnace used in activated carbon production 
at about $95{ }^{\circ} \mathrm{C}$ for $0.5 \mathrm{~h}$, strained and rinsed with warm pure water till neutral $\mathrm{pH}$, desiccated at $110^{\circ} \mathrm{C}$ in a furnace for just about $12 \mathrm{~h}$ and weighed to compute the yield.

\section{RESULTS AND DISCUSSION}

Yield and specific surface BET: Influences of carbonization temperature on the surface field (S) and yield (\%) of activated carbon were assess below the terms of the impregnation rate of $1 / 1(\mathrm{~g} / \mathrm{g})$ and carbonization period of $2 \mathrm{~h}$. The carbon yield was computed based on the mass of Eriobotrya japonica (EJ) seed on a dry base from the following equality:

$$
\text { Carbon yield }(\mathrm{wt} \%)=\frac{\text { Weight of activated carbon }(\mathrm{g})}{\text { Weight of EJ seed }(\mathrm{g})} \times 100
$$

The most important study parameters affecting the yield of activated carbon are carbonization temperature, carbonization duration and impregnation rate. As seen from Table-1, with the rising in carbonization temperature, the yield of active carbon increased. This may be connected to the promotion of carbon flaming-off, tar evaporation and the vaporization of biomass would be increased because of rise of temperature $[22,23]$. The specific surface BET of activated carbons for diverse carbonization temperatures were detected by nitrogen adsorption at $77.3 \mathrm{~K}$. The surface field has changed in direct proportion to the temperature. As viewed from the Table-2, when temperature rised from 500 to $700{ }^{\circ} \mathrm{C}$, the $\mathrm{S}_{\mathrm{BET}}, \mathrm{S}_{\mathrm{mic}}, \mathrm{S}_{\mathrm{ext}}$, $\mathrm{V}_{\mathrm{t}}, \mathrm{V}_{\text {mic }}$ and $\mathrm{D}_{\mathrm{p}}$ values increased from 863.3 to $1079 \mathrm{~m}^{2} / \mathrm{g}$, from 207.0 to 417.0 , from 656.3 to 662.2 , from 0.44 to $0.52 \mathrm{~cm}^{3} / \mathrm{g}$, from 0.09 to 0.19 and from 3.31 to $3.55 \mathrm{~nm}$, respectively. This increase, is thought to be due to the continued deterioration of the volatile components of activated carbon as the temperature rises and the formation of new pores. As a result, $700^{\circ} \mathrm{C}$ was selected as the ideal carbonization temperature in order to the best pore area and yield. The BET surface field of active carbon produced at $600{ }^{\circ} \mathrm{C}$ was not measured.

\section{TABLE-1}

EFFECT OF EXPERIMENTAL PARAMETERS ON THE YIELD OF ACTIVATED CARBON SAMPLES

\begin{tabular}{ccccc}
\hline Sample & $\begin{array}{c}\text { Impregnation } \\
\text { rate }\end{array}$ & $\begin{array}{c}\text { Carbonization } \\
\text { temperature } \\
\left({ }^{\circ} \mathrm{C}\right)\end{array}$ & $\begin{array}{c}\text { Carbonization } \\
\text { time (hold } \\
\text { time) }(\min )\end{array}$ & $\begin{array}{c}\text { Yield } \\
(\%)\end{array}$ \\
\hline $\mathrm{AC} 1$ & $1 / 1$ & 500 & 120 & 42.58 \\
$\mathrm{AC} 2$ & $1 / 1$ & 600 & 120 & 43.09 \\
$\mathrm{AC} 3$ & $1 / 1$ & 700 & 120 & 43.40 \\
\hline
\end{tabular}

TABLE-2

STRUCTURAL CHARACTERISTICS OF ACTIVATED CARBON

\begin{tabular}{lccc}
\hline \multicolumn{1}{c}{ Structural properties } & AC1 & AC2 & AC3 \\
\hline BET surface area, $\mathrm{S}_{\mathrm{BET}}\left(\mathrm{m}^{2} / \mathrm{g}\right)$ & 863.3 & $\mathrm{ND}^{*}$ & 1079 \\
Micropore area, $\mathrm{S}_{\mathrm{MIC}}\left(\mathrm{m}^{2} / \mathrm{g}\right)$ & 207.0 & & 417.0 \\
External surface area, $\mathrm{S}_{\mathrm{EXT}}\left(\mathrm{m}^{2} / \mathrm{g}\right)$ & 656.3 & & 662.2 \\
Total pore volume, $\mathrm{V}_{\mathrm{t}}\left(\mathrm{cm}^{3} / \mathrm{g}\right)$ & 0.44 & & 0.52 \\
t-plot micropore volume, $\mathrm{V}_{\mathrm{MIC}}\left(\mathrm{cm}^{3} / \mathrm{g}\right)$ & 0.09 & & 0.19 \\
Average pore size, $\mathrm{D}_{\mathrm{P}}(\mathrm{nm})$ & 3.31 & & 3.55 \\
\hline$* \mathrm{ND}=$ None detected & & &
\end{tabular}

Adsorption isotherms: The chemical properties of the adsorbent, the porous structure and the heat adsorption are determined with adsorption isotherms. The porosity of acti- vated carbon substances is generally described by handling $\mathrm{N}_{2}$ adsorption method [24]. Fig. 3 shows the $\mathrm{N}_{2}$ adsorption/ desorption isotherms at $77.3 \mathrm{~K}$ of the three dissimilar activated carbon examples made from Eriobotrya japonica seed. The isotherm created from these works were found to follow the tendency of complex Type I and Type IV isotherms accordingly to the International Union of Pure and Applied Chemistry (IUPAC) [25].

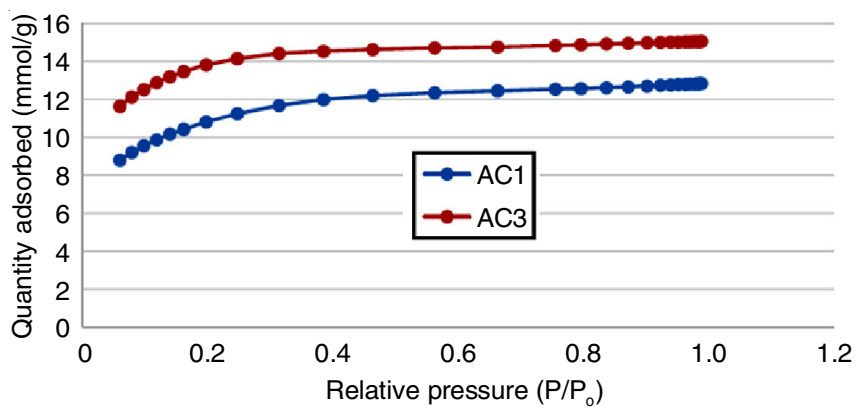

Fig. 3. $\mathrm{N}_{2}$ adsorption and desorption isotherms of Eriobotrya japonica seed produced activated carbon

Pore magnitude distribituan is a very important property of poriferous sorbents because the dissimilarity in the pore magnitude effects the adsorption capability in order to molecules of distinct dimensions and shape. According to the rating IUP activated carbon accepts, sorbent pores are examined in three groups as micropores $(<2 \mathrm{~nm})$, mesopores $(2-50 \mathrm{~nm})$ and macropores (>50 nm) [26]. Fig. 4 shows that large surface area activated carbon was obtained. The curves formed at low pressure show adsorption into the micropores [27]. The increase in the graph indicates the growth of the pores and the improving of mesopores.

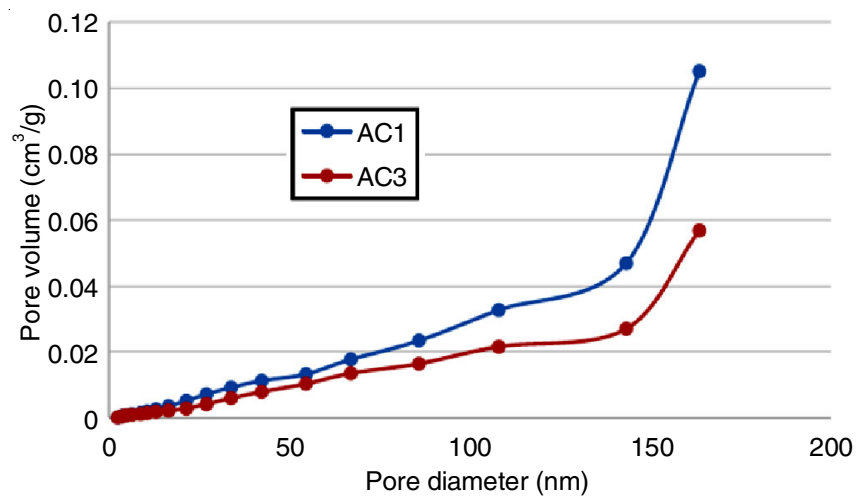

Fig. 4. Pore size distributions and $\mathrm{N}_{2}$ adsorption of activated carbon

SEM analysis: SEM views of activated carbons produced at distinct temperatures are given in Figs. 5-7.

SEM technique was used to watch the surface physical features of the activated carbon. According to Figs. 5-7; when the SEM images of 1000 and 2000 fold magnifications of each active carbon are taken, activated carbon has a porous structure. The obtained activated carbon displayed a highly porous structure with various sizes of mesopores and macropores. Micropores were observed at this resolution. Additionally, a three dimensional interconnected and irregular mesopore structure can also be clearly observed. These pores are caused by the 

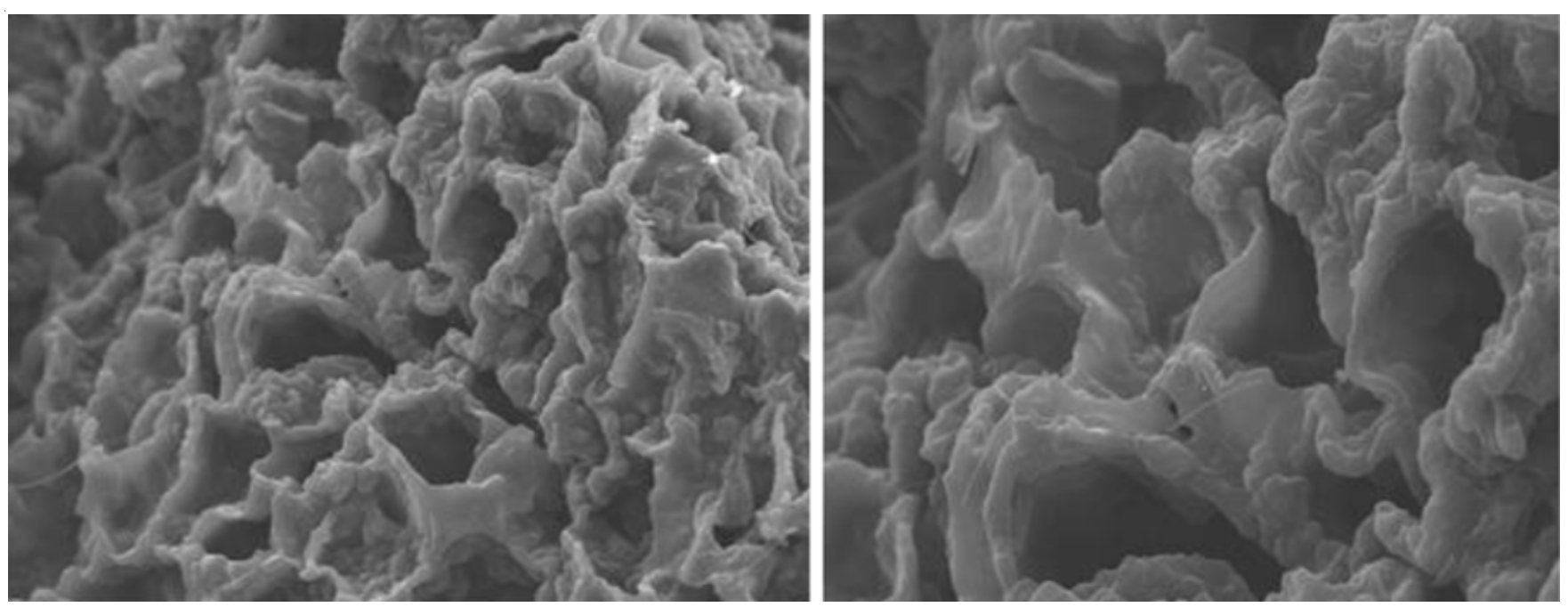

Fig. 5. SEM images of activated carbon produced at $500{ }^{\circ} \mathrm{C}$ carbonization temperature
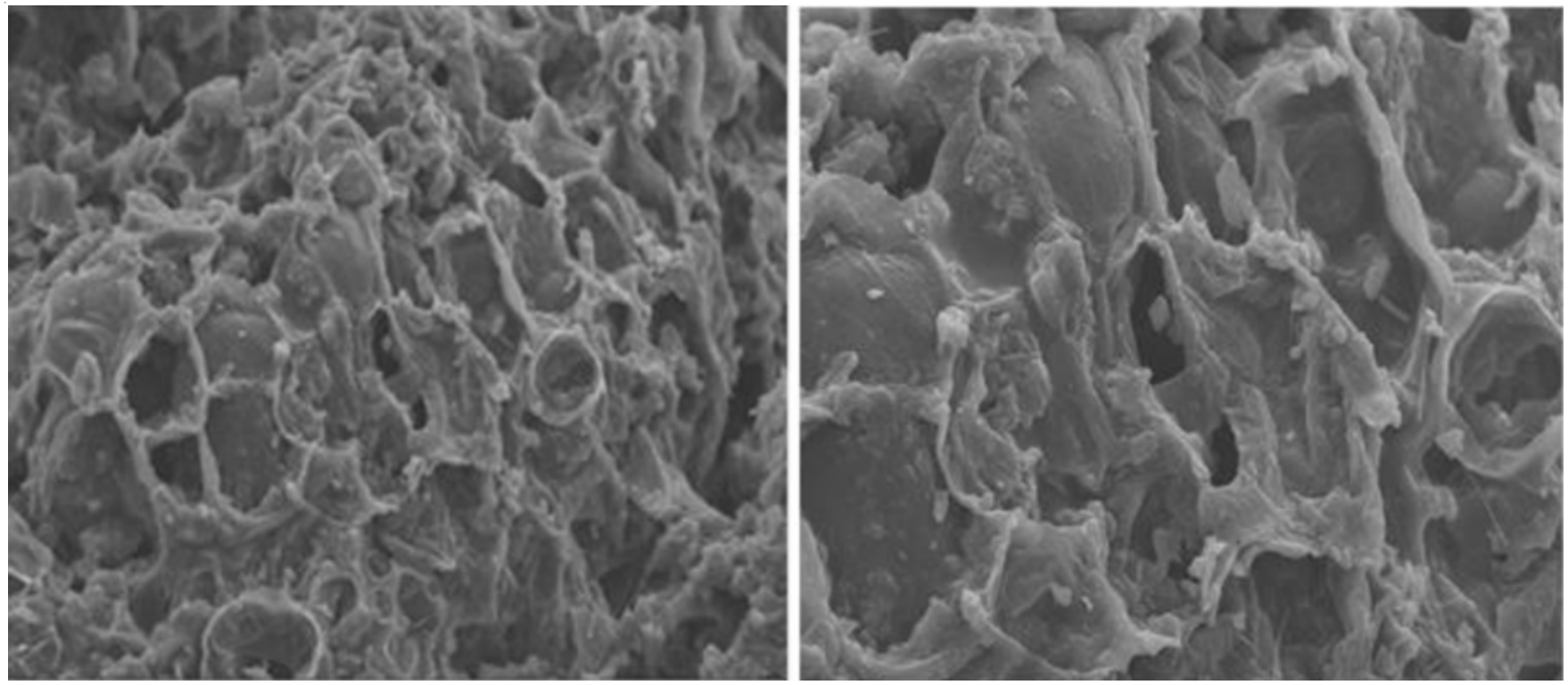

Fig. 6. SEM images of activated carbon produced at $600{ }^{\circ} \mathrm{C}$ carbonization temperature
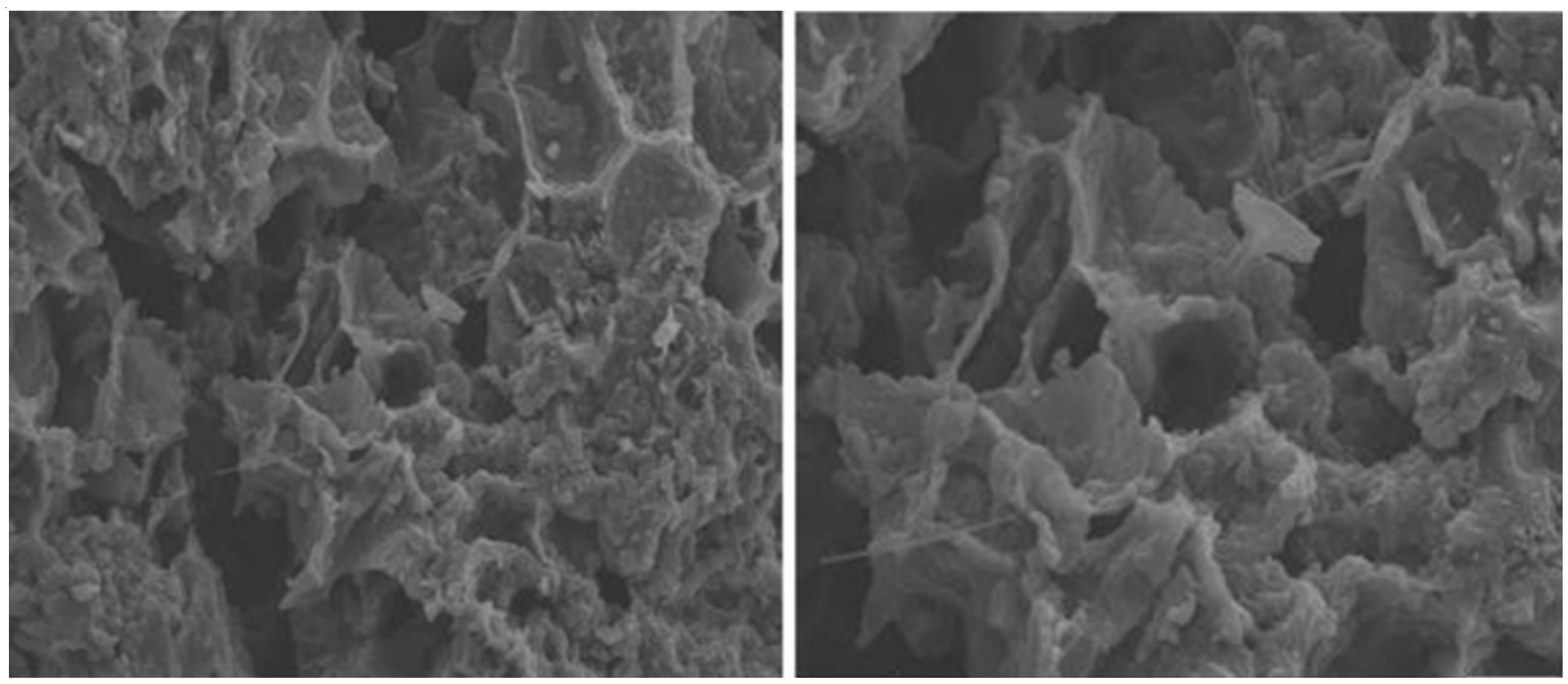

Fig. 7. SEM images of activated carbon produced at $700^{\circ} \mathrm{C}$ carbonization temperature 
evaporation of the $\mathrm{ZnCl}_{2}$ chemical agent during carbonization to leave free space [28]. The mesopores can offer adsorption sites for goal contaminants.

Fourier transform infrared spectroscopy (FT-IR): The FT-IR spectra of active carbon produced at $500{ }^{\circ} \mathrm{C}$ and $700{ }^{\circ} \mathrm{C}$ is given in Fig. 8.

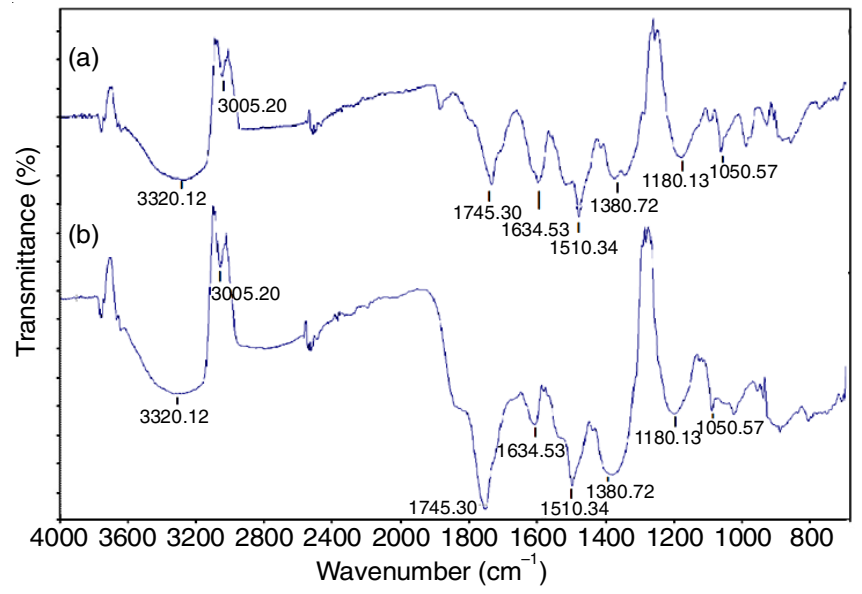

Fig. 8. FT-IR spectra with carbonization temperatures of $500{ }^{\circ} \mathrm{C}$ (a) and $700{ }^{\circ} \mathrm{C}(\mathrm{b})$

The spectra show a number of absorption peaks defining the compound structure of the materials. According to Fig. 8, the existence of the wide and intensive absorption peak at 3320.12 $\mathrm{cm}^{-1}$ shows the O-H stretching oscillation of cellulose, hemicellulose, absorbed water, pectin and lignin. The peak appeared at $3005.2 \mathrm{~cm}^{-1}$ may be assign to the aliphatic satiated C-H tension oscillations of in lignin polysaccharides bearing cellulose and hemicellulose [29]. The peak at $1745.30 \mathrm{~cm}^{-1}$ display the carbonyl $(\mathrm{C}=\mathrm{O})$ tension oscillation of the carboxyl classes of pectin, hemicellulose and lignin [30]. The peak at 1634.53 $\mathrm{cm}^{-1}$ may be due to adsorbed water H-O-H bend. The oscillation at $1510.34 \mathrm{~cm}^{-1}$ and $1380.72 \mathrm{~cm}^{-1}$ could be owing to aliphatic and aromatic $(\mathrm{C}-\mathrm{H})$ groups in the horizontal oscillation of methyl, methoxy and methylene groups. The band at 1180.13 $\mathrm{cm}^{-1}$ is due to the $\mathrm{C}-\mathrm{O}$ stretching oscillation of phenol group $[31,32]$. The band seen nearby $1634.53 \mathrm{~cm}^{-1}$, could be ascribe to $(\mathrm{C}=\mathrm{C})$ vibration in aromatic rings [33]. The peaks in the range of $1250-1000 \mathrm{~cm}^{-1}$ may belong to the $\mathrm{C}-\mathrm{O}$ stretching oscillation of alcohols and carboxylic acids [32]. Many absorption peaks were not observed while the carbonization temperature increased. This is probably due to the evaporation of organic substances at high temperatures.

Thermal analysis: The TGA curve showing the $\%$ mass change of activated carbon produced by $\mathrm{ZnCl}_{2}$ activation in Fig. 9. When TGA curve of active carbon produced by $\mathrm{ZnCl}_{2}$ activation are taken into account, it is seen that the initial mass loss is around $8.29 \%$ at $25-109^{\circ} \mathrm{C}$. This reduction is thought to be caused by the removal of phenolic groups from the environment. The second mass loss is about $4.18 \%$ at 109$445^{\circ} \mathrm{C}$ and the third mass loss is around $11.75 \%$ at $445-660$ ${ }^{\circ} \mathrm{C}$. The total mass loss is $2.11 \mathrm{mg}(24.22 \%)$.

XRD analysis: XRD models of the activated carbon are indicated in Fig. 10. According to Fig. 4, activated carbon sample exhibit with five broad peaks corresponding to

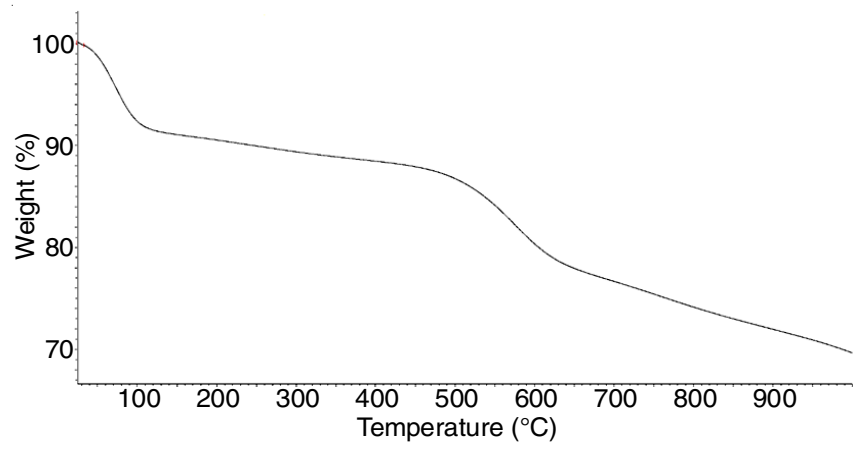

Fig 9. TGA curve of the activated carbon

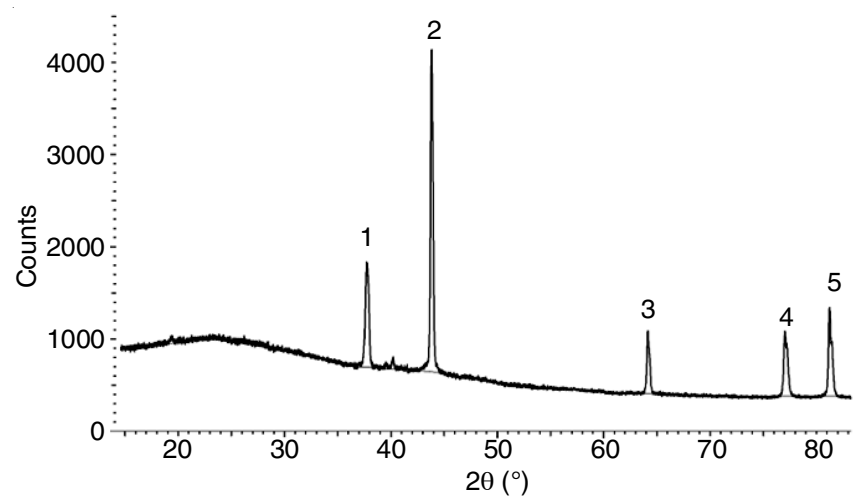

Fig. 10. XRD patterns of activated carbon

$2 \theta=38.9^{\circ}, 44.1^{\circ}, 64.5^{\circ}, 77.6^{\circ}$ and $80.9^{\circ}$. When the elemental pairings of the peaks are made 2, 3 and 5th peaks are formed $\mathrm{C}-\mathrm{C}$ bonds, 1th peak is formed $\mathrm{Zn}-\mathrm{H}$ and 4 th peak is formed $\mathrm{H}-\mathrm{H}$. The presence of many C-C pairs shows less impurities.

\section{Conclusion}

In this study, active carbon was produced from Eriobotrya japonica seed using chemical activation method with $\mathrm{ZnCl}_{2}$ agent. Activated carbon was produced at three different carbonization temperatures $\left(500,600,700{ }^{\circ} \mathrm{C}\right)$. The highest BET surface field $\left(1079 \mathrm{~m}^{2} / \mathrm{g}\right)$, micropore surface area $\left(417 \mathrm{~m}^{2} / \mathrm{g}\right)$ and total micropore volume $\left(0.52 \mathrm{~cm}^{3} / \mathrm{g}\right)$ were obtained below the following terms: impregnation ratio of $1 / 1$, activation temperature of $700{ }^{\circ} \mathrm{C}$ and activation time of $2 \mathrm{~h}$. This suggests that $\mathrm{ZnCl}_{2}$ is a activating agent in order to producing activated carbon by an improved microporous structure. The results show that the chemical activation with $\mathrm{ZnCl}_{2}$ from Eriobotrya japonica seed is good in terms of specific surface field, pore improvement and the structural order of activated carbon. Eriobotrya japonica activated carbon- $\mathrm{ZnCl}_{2}$ can be contemplated as an excellent low-cost and eco-friendly adsorbent.

\section{ACKNOWLEDGEMENTS}

The authors are grateful for he financial support of the Scientific Research Project of Karamanoglu Mehmetbey University, Karaman, Turkey (Project Number 01-D-17).

\section{REFERENCES}

1. H.P.S. Khalil, M. Jawaid, P. Firoozian, U. Rashid, A. Islam and H.M. Akil, J. Biobased Mater. Bioenergy, 7, 708 (2013); https://doi.org/10.1166/jbmb.2013.1379.

2. D. Kalderis, D. Koutoulakis, P. Paraskeva, E. Diamadopoulos, E. Otal, J.O. Valle and C. Fernández-Pereira, Chem. Eng. J., 144, 42 (2008); https://doi.org/10.1016/j.cej.2008.01.007. 
3. O. Ioannidou and A. Zabaniotou, Renew. Sustain. Energy Rev., 11, 1966 (2007);

https://doi.org/10.1016/j.rser.2006.03.013.

4. P.T. Williams and A.R. Reed, Biomass Bioenergy, 30, 144 (2006); https://doi.org/10.1016/j.biombioe.2005.11.006.

5. C. Saka, J. Anal. Appl. Pyrolysis, 95, 21 (2012); https://doi.org/10.1016/j.jaap.2011.12.020.

6. Ö. Sahin and C. Saka, Bioresour. Technol., 136, 163 (2013); https://doi.org/10.1016/j.biortech.2013.02.074.

7. H. Dolas, O. Sahin, C. Saka and H. Demir, Chem. Eng. J., 166, 191 (2011); https://doi.org/10.1016/j.cej.2010.10.061.

8. M. Özdemir, T. Bolgaz, C. Saka and Ö. Sahin, J. Anal. Appl. Pyrolysis, 92, 171 (2011); https://doi.org/10.1016/j.jaap.2011.05.010.

9. R.R. Bansode, J.N. Losso, W.E. Marshall, R.M. Rao and R.J. Portier, Bioresour. Technol., 90, 175 (2003); https://doi.org/10.1016/S0960-8524(03)00117-2.

10. D. Savova, E. Apak, E. Ekinci, F. Yardim, N. Petrov, T. Budinova, M. Razvigorova and V. Minkova, Biomass Bioenergy, 21, 133 (2001); https://doi.org/10.1016/S0961-9534(01)00027-7.

11. P.K. Malik, Dyes Pigments, 56, 239 (2003); https://doi.org/10.1016/S0143-7208(02)00159-6.

12. A. Aygün, S. Yenisoy-Karakas and I. Duman, Micropor. Mesopor. Mater., 66, 189 (2003); https://doi.org/10.1016/j.micromeso.2003.08.028.

13. A.A. Bagreev, A.P. Broshnik, V.V. Strelko and Y.A. Tarasenko, Russ. J. Appl. Chem., 74, 205 (2001); https://doi.org/10.1023/A:1012757730582.

14. Z.Z. Chowdhury, S.B. Abd Hamid, R. Das, M.R. Hasan, S.M. Zain, K. Khalid and M.N. Uddin, BioResources, 8, 6523 (2013); https://doi.org/10.15376/biores.8.4.6523-6555.

15. J. Guo and A.C. Lua, J. Therm. Anal. Calorim., 60, 417 (2000); https://doi.org/10.1023/A:1010137308378.

16. S.G. Herawan, M.S. Hadi, M.R. Ayob and A. Putra, Sci. World J., Article ID 624865 (2013); https://doi.org/10.1155/2013/624865.

17. J. Katesa, S. Junpirom and C. Tangsathitkulchai, Suranaree J. Sci. Technol., 20, 269 (2013).

18. V. Sricharoenchaikul, C. Pechyen, D. Aht-ong and D. Atong, Energy Fuels, 22, 31 (2008); https://doi.org/10.1021/ef700285u.
19. N. Mohamad Nor, L.C. Lau, K.T. Lee and A.R. Mohamed, J. Environ. Chem. Eng., 1, 658 (2013); https://doi.org/10.1016/j.jece.2013.09.017.

20. M.A. Lillo-Ródenas, D. Cazorla-Amorós and A. Linares-Solano, Carbon, 41, 267 (2003); https://doi.org/10.1016/S0008-6223(02)00279-8.

21. A. Sánchez-Sánchez, F. Suárez-García, A. Martínez-Alonso and J.M. Tascón, ACS Appl. Mater. Interfaces, 6, 21237 (2014); https://doi.org/10.1021/am506176e.

22. Q. Qian, M. Machida and H. Tatsumoto, Bioresour. Technol., 98, 353 (2007); https://doi.org/10.1016/j.biortech.2005.12.023.

23. Q. Lu, Z. Wang, C.Q. Dong, Z.F. Zhang, Y. Zhang, Y.P. Yang and X.F. Zhu, J. Anal. Appl. Pyrolysis, 91, 273 (2011); https://doi.org/10.1016/j.jaap.2011.03.002.

24. X. Wang, D. Li, W. Li, J. Peng, H. Xia, L. Zhang, S. Guo and G. Chen, BioResources, 8, 6184 (2013).

25. K.S.W. Sing, Pure Appl. Chem., 54, 2201 (1982); https://doi.org/10.1351/pac198254112201.

26. H. Xiao, H. Peng, S. Deng, X. Yang, Y. Zhang and Y. Li, Bioresour. Technol., 111, 127 (2012); https://doi.org/10.1016/j.biortech.2012.02.054.

27. W. Wang and D. Yuan, Sci. Rep., 4, 5711 (2015); https://doi.org/10.1038/srep05711.

28. H. Deng, G. Li, H. Yang, J. Tang and J. Tang, Chem. Eng. J., 163, 373 (2010); https://doi.org/10.1016/j.cej.2010.08.019.

29. A. Gundogdu, C. Duran, H.B. Senturk, M. Soylak, M. Imamoglu and Y. Onal, J. Anal. Appl. Pyrolysis, 104, 249 (2013); https://doi.org/10.1016/j.jaap.2013.07.008.

30. V.O. Njoku, K.Y. Foo and B.H. Hameed, Chem. Eng. J., 215-216, 383 (2013); https://doi.org/10.1016/j.cej.2012.10.068.

31. B.H. Hameed and F.B.M. Daud, Chem. Eng. J., 139, 48 (2008); https://doi.org/10.1016/j.cej.2007.07.089.

32. D. Angin, Fuel, 115, 804 (2014); https://doi.org/10.1016/j.fuel.2013.04.060.

33. A.C. Lua and T. Yang, J. Colloid Interface Sci., 290, 505 (2005); https://doi.org/10.1016/j.jcis.2005.04.063. 